\title{
Hefting onto Place: Intersecting Lives of Humans and Sheep on Scottish Hills Landscape
}

\author{
John Gray
}

To cite this article: John Gray (2014) Hefting onto Place: Intersecting Lives of Humans and Sheep on Scottish Hills Landscape, Anthrozoös, 27:2, 219-234, DOI: 10.2752/175303714X13903827487520

To link to this article: https://doi.org/10.2752/175303714X13903827487520

\section{曲 Published online: 01 May 2015.}

Submit your article to this journal




\section{Hefting onto Place:} Intersecting Lives of Humans and Sheep on Scottish Hills Landscape

\section{John Gray \\ Department of Anthropology and Development Studies, University of Adelaide, Australia}

Address for correspondence: John Gray, Department of Anthropology and Development Studies, University of Adelaide, Adelaide, South Australia 5005, Australia. E-mail: john.gray@adelaide.edu.au
ABSTRACT This paper analyzes the phenomenon called hefting of sheep onto the landscape of hill sheep farms in the Scottish Borders. It is based upon data collected during extended periods of ethnographic fieldwork beginning in 1981 and continuing to the present. Hefting is the term used by sheep farmers for the natural tendency of hill sheep to graze, remain, and bond onto specific areas of the landscape without the need for fencing. The herding practices of hill sheep farms appropriate hefting in flock management and breeding. The analysis of hefting makes two contributions to understanding human-animal relations. First, because the of the centrality of territorial bonding, hefting makes explicit that we should always be ready to include a third dimension-place and emplacement-in understanding human-animal relations. Second, drawing on Haraway's concept of "becoming with," hefting and herding demonstrate the fundamentally relational character of human-animal-place relations.

Keywords: emplacement, family farm, hefting, shepherding

One of the characteristics of hill and upland sheep farming in the UK is the phenomenon known as "hefting." It refers to an instinctive territoriality of hill sheep and a recognized system of flock management that has been used in the UK since the seventeenth century and "taken up in Scotland after the clearances, starting in the eighteenth century which saw the establishment of large-scale 'sheep walks'" (ADAS 2008, p. 1). It is a multi-dimensional phenomenon incorporating animal biology, agricultural science and, as I will argue, relational configuration of humans, animals, and land in which shepherds and sheep-in their own way according to their particular abilities (Chemero 2003, pp. 189-190)create an embodied sense of place through mutually attending to each other's motivated movements over the landscape. 
In terms of animal biology, hefting is defined in the literature of scientific research (see ADAS 2008) and by experienced herdsmen (e.g., Hart 2004) as the "natural" or "instinctual" territoriality of certain breeds of wild and feral sheep, particularly their predisposition to remain and breed on the specific regions of the hills landscape where they live. Sheep breeds that have this hefting instinct are usually raised in locales characterized by poor soil, low-nutrition vegetation, and weather conditions not conducive to intensive arable or livestock farming (The Hill Farming Research Organisation 1979, pp. 9-21). Hill and upland farmers use hefting to manage their flocks. By keeping sheep and their lambs on the same area over generations, they adapt to the particularities of the topography, soils, and weather of the terrain on which they live without the need for fencing. Both the group of sheep and the landscape upon which they graze are called a "heft" [or cut]. Such flock management entails an intimacy in human-animal-land relations. As one farmer noted: "This [hefting] "homing instinct" is the result of centuries of evolution ... Hefted sheep cannot be understood in isolation. The sheep are inseparable from the farmers who live and care for the land where the sheep live. The hill farmers also, are a knowing and wise breed. A breed apart and a rare breed themselves; they are involved in the land which in turn is in their blood" (Goddard n.d.). Here the farmer captures the essence of hefting as the intersection of the lives of humans and animals with landscape that I found to be practiced by hill sheep farmers whose sheep graze the hills of Teviotdale in the Scottish Borders region. My aim for this paper, then, is to analyze hefting as a relational configuration of sheep and shepherds in their movements through the landscape as mutual acts of emplacement. Moreover, as I will argue, it is an intertwining of lives that transforms the very being of sheep and people so that attachment to land is "in the blood" or as the people of Teviothead say, "bred into you."

In this analysis, I make two contributions to our understanding of human-animal relations. The first is, in being a phenomenon in which the herding practices of shepherds incorporate the territoriality of sheep grazing patterns, hefting makes explicit that in analyzing humananimal relations we should always be ready to include a third dimension-place. In developing this theme I draw on Casey's argument that being-in-place is a primordial experience fundamental to being-in-the-world (1993, 1996:16ff). Place is not a location in some preexisting abstract space. Instead, place "serves as the condition of all existing things. This means that, far from being merely locator or situational, place belongs to the very concept of existence" (1993, p. 15). "We are not only in places but of them" (Casey 1996, p. 19). While his argument concerns the human experience of place, it can, as I show in the following analysis, be extended to animals: beings (both human and nonhuman) are always somewhere, in some location that is actively and constitutively perceived through the body's senses, movements, and practical engagements (Heidegger 1962) so that the places inhabited come to have particular significances in what Heidegger calls "dwelling" (1975). For animals such significances of places take the form of "affordances" (Gibson 1979 and Chemero 2003), while for humans they take the form of meanings (de Certeau 1984; Thomas 1993; Basso 1996).

While there have been advances in the way we understand human's relation to nonhuman species, they still retain a dualistic perspective. For example, John Knight's collection, Animals in Person: Cultural Perspective on Human-Animal Intimacies (2005), established a new direction in understanding human-animal relations. Previously, anthropologists had largely drawn upon Levi-Strauss' dictum that animals are "good to think" (1963, p. 89) to analyze how humans use animals - in both their similarities and differences to humans - as symbolic models to provide conceptual and classificatory frameworks to think about such things as the nature of themselves and others, the structure of the social world, and the production of social identities (Mullin 1999). 
Knight's critique of this "symbolic reductionism" is that animals are treated as merely passive objects of human thought. Instead, he argues that we should treat animals as subjects and active agents in their intimate relations with humans, including being sensitive to their species-specific characteristics and capacities that affect interactions with humans (2005, pp. 1, 9). ${ }^{1}$ He also is critical of the contrastive logic that separates humans and animals. Instead, he argues for a "readiness to look beyond it and address the issue of human-animal commonality and continuity" (2005, p. 3). However, in making these contributions, he retains the implicit presumption that the relationship is between only two elements-humans and animals.

One theme in the following analysis of hefting, then, is that human-animal relations take place somewhere and this somewhere is more than a neutral backdrop which should be explicitly included so that place and the way human and nonhuman beings create and relate to it are seen to constitute a trinary rather than a dualistic relation. In the following analysis, I explain how living with the landscape through grazing, mating, giving birth, and mothering their lambsall involving movement over and active engagement with the landscape-hill sheep create a place, called a heft, to which they become attached and whose characteristics they come to embody in their physical attributes and genetic makeup.

Because hefting sheep embody the landscape in their acts of emplacement, they also are their relation to the landscape. This is the second contribution of this analysis of hefting: the fundamental relationality of the trinary configuration of human, animals and place. ${ }^{2}$ While Haraway's work also has a dualistic focus on human and nonhuman, she is critical of the attributing of any significance to boundary between them that derives from "the culturally normal fantasy of human exceptionalism" (2008, p. 11). Instead, she focuses on the connections and interdependencies, that is, on the relations between humans and nonhuman species that are central to the constitution of botha process which she so incisively calls "becoming with" (2008, p. 1).

At first, Latour's Actor Network Theory (2005) provides a possible framework for the analysis of hefting and the sense of place that is emergent in it. This is because of its non-dualistic and non-reductive inclusion of nonhuman beings and inanimate objects, as well has humans as participants in the multi-nodal networks or assemblages that constitute social life. More than just the inclusions, fundamental to Actor Network Theory is that every element-animate or inanimate-in the network actively contributes to its functioning and outcomes. Accordingly, Actor Network Theory demands the analysis of the part played by each element or "actant" (Latour 2005, p. 54) of the assemblage such that agency - "making some difference to a state of affairs, transforming some As into Bs ... " (Latour 2005, pp. 52-53) -is distributed throughout the network and is not limited to humans. So in Latour's terms, hefting on Border hill sheep farms is a network of relations between the border hills landscape (including the terrain, soils, vegetation, and climatic conditions), the breeds of sheep whose genetic makeup enable them to survive in it, and the herding practices of hill farmers; each is an actant in the hefting network whose "agencies" can be analyzed in terms of "doing something, that is, making some difference to a state of affairs" (2005, p. 52), in this case, to the sense of place created by sheep and shepherds through their participation in the hefting. However, Latour's network is more actant-centered than relational because it assumes that each actant is a separate element with pre-existing capacities that are brought to the network, shape the relations between actants and the characteristics of the actants' integration into a network. Accordingly, in this paper I adopt a critical perspective on Actor Network Theory because it uses what might be called an epiphenomenal relationality in which the actants' agencies precede and constitute their network relations rather than a fundamental relationality of becoming with their network 


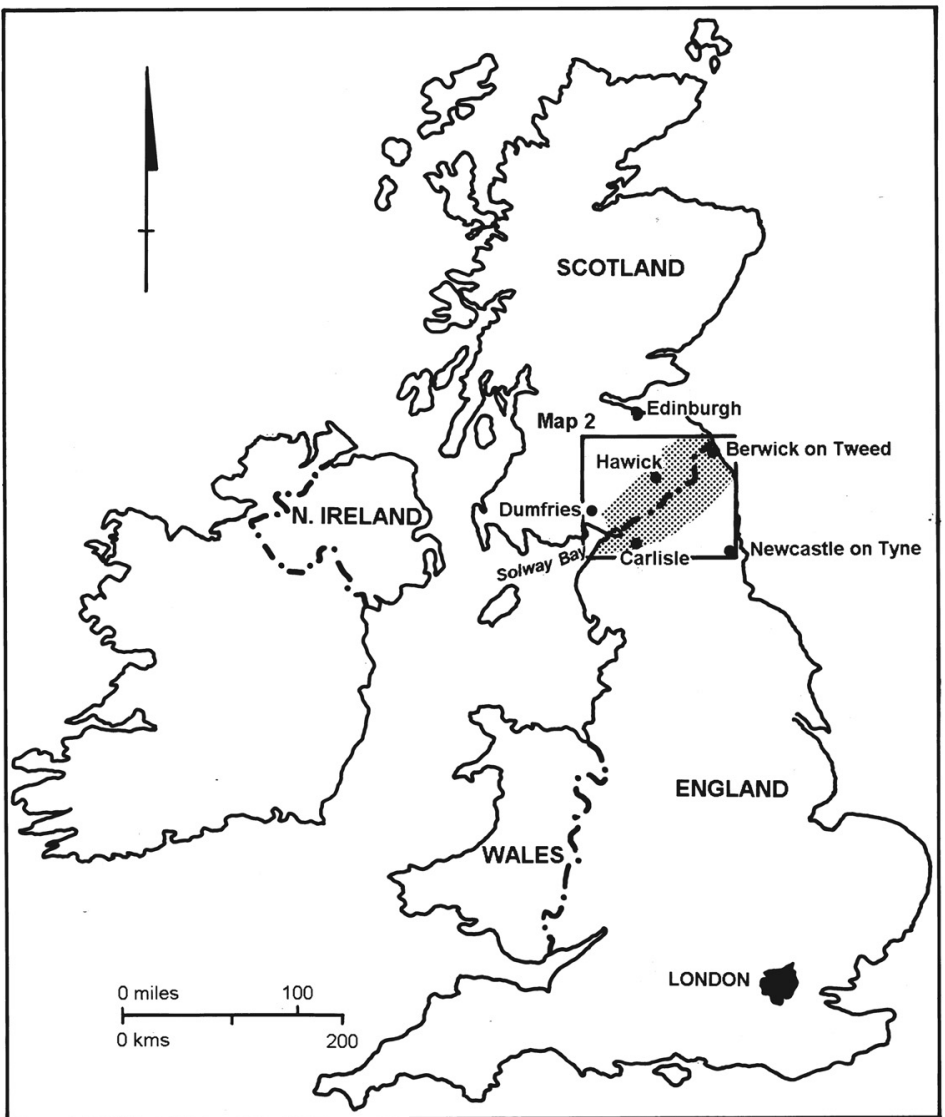

Figure 1. Borders region (shaded). Copyright author.

relations (see Ingold 2011, pp. 89-94). So, just as sheep are their relations to the landscape, I also analyze how shepherds are and become with their relations to sheep in their herding practices and how, mediated by sheep becoming with the landscape through hefting/emplacement onto it, a sheep farming family is and becomes with their relations to the landscape to form a family farm. In other words, a sheep's hefting relation to, embodiment of, and emplacement with, the landscape mediates a sheep farming family's relation to their farm and their sense of place as a family farm.

The following analysis and its conclusions are based upon extended periods of ethnographic research in Teviothead totaling nearly three years that began in 1981 and continues to the present. During these periods of research the methods used included principally participant observation with farmers, shepherds and their families on all the farms in Teviothead as they carried out the daily activities of breeding and raising sheep, attended auctions of lambs, ewes and rams, planned and participated in local agricultural shows, engaged in leisure and community activities. In relation to the present paper, one of the main tasks of shepherds and farmers is to walk or bike around the hill caring for their sheep, and I accompanied each of them several times in order to collect data on their knowledge of sheep, the hills landscape, and other facets of shepherding. 


\section{Teviotdale Hill Sheep Farms}

Teviotdale is a locality in the Borders Region of Scotland (see Figure 1). It consists of approximately 200 residents of 15 hill sheep farms ${ }^{3}$ and nearly 30 cottages that straddle an 18 kilometer stretch of the River Teviot from its source to the mill town of Hawick. Hill sheep farms in Teviotdale range in size from 160 to over 2,000 hectares, with flocks from 450 to 2,000 breeding ewes. The principal farming activity is rearing ewes whose lambs are sold for food consumption in Britain and the European Union. ${ }^{4}$

Teviotdale hill sheep farms are family-farms ${ }^{5}$ occupied under three types of tenure-owner occupation, traditional tenancy, and partnerships. ${ }^{6}$ The length of tenure ranges from first generation of a family on four tenant farms to families of two to three generations on most of the other farms. The longest tenancy is over 140 years on one of the farms. While there is wide variation in the length of tenure, most of the families occupying farms envision and value them as family farms that are central to their hill sheep farming way of life and to the character of their community and, as a result, make plans for them to be passed to the next generation. In doing so, as I describe later in the essay, they literally and figuratively incorporate the sense of place emergent in hefting.

The terrain of Teviotdale consists of hills reaching 600 meters at the watershed and gradually decreasing in height and density with the widening of the valley as one moves in a north-easterly direction toward Hawick. There are two types of land-"outbye," hill or rough grazing, and "inbye," park or improved grassland (see Figure 2). The two are differentiated in terms of weather conditions, topography, soil, vegetation, and the consequent affordance for rearing sheep. All farms in the valley have some of both types of land. The nine larger farms (over 500 hectares) on the higher ground nearer the watershed have a greater proportion of hill land (more than $75 \%$ ), and the six smaller farms nearer Hawick on generally lower ground have a smaller proportion of hill land (less than 50\%).

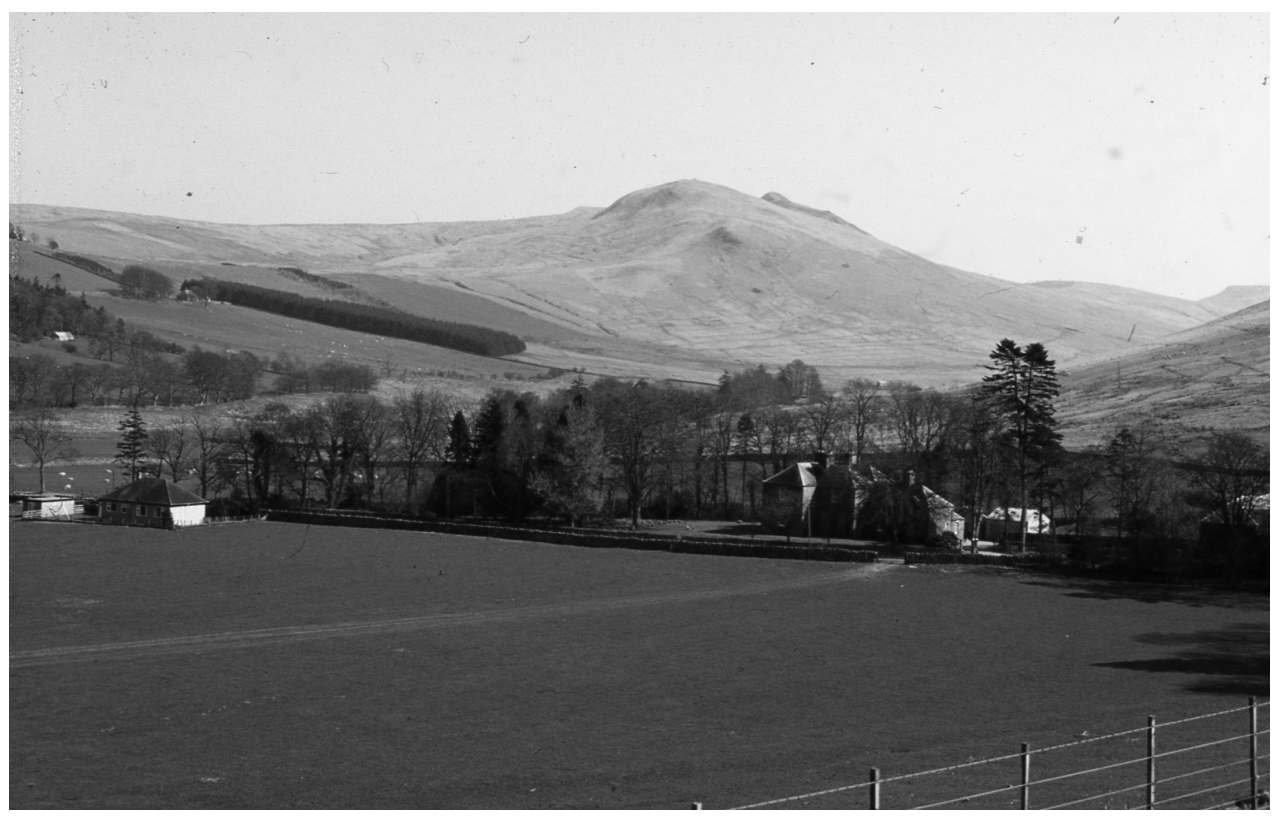

Figure 2. Inbye (foreground) and outbye land. Copyright author. 


\section{Becoming with the Landscape: Hefting and Emplacement Affordances of Inbye and Outbye Landscape}

The landscape of the border hills is not a passive backdrop for the activities of sheep and sheep farmers. Instead, it is related to them in terms of its "affordances." The concept of affordance was originally developed by Gibson (1979) to identify "an action possibility available in the environment to an individual independent of the individual's ability to perceive this possibility" (McGrenere and Ho 2000, p. 2), that is, "the perceived and actual properties of a thing, primarily those that determine just how the thing could possibly be used [by humans]" (Norman 1998, p. 9, brackets added). While Gibson's concept of affordance recognizes an active interaction between an individual being (whether human or nonhuman) and the environment, it lacks a strong sense of relationality because it attributes pre-existing qualities to the environment that are independent of any perception of them. ${ }^{7}$ However, for Chemero affordances are truly relations between animals and features of their environment (2003, p. 186) so that, in relation to the outbye of hill land Border hill sheep farms, its productive potential is neither solely the pre-existing property of the landscape itself nor is it exclusively derived from the subjectivity or intentionality of the farmers and shepherds engaging with it (Knappett 2004, p. 46). It is the relation between the landscape and the farmers/shepherds that "has" the particular affordance or opportunity of productive use by particular breeds of hill sheep. I use the term landscape ${ }^{8}$ rather than environment because the idea of environment, as we saw with Gibson, implies a pre-existing external and separate surrounding context whose properties affect the lives [survival, development, and evolution] of beings that exist within it. One sense of landscape identified by Olwig has a more relational and becoming rather than a pre-existing and causative character, as "land 'scaped,' 'shaped' or created as a place ... by people through their practice ... Landscape is shaped in large measure through doing" (2008, pp. 82-84). What I add to Olwig's concept of doing [and becoming landscape] is that in hefting the doing is done by both humans and animals.

For sheep farmers, the affording features of the outbye landscape are its altitude, climatic conditions, soil, and vegetation that make it unsuitable for arable cultivation and for all but the hardiest sheep (see Hill Farm Research Organisation 1979, pp. 9-19). ${ }^{9}$ Outbye land lies at altitudes above 300 meters. It has a complex topography and a correspondingly rich descriptive nomenclature consisting of hills (law [conical hill], pen [pointed hill]), hilltops (heid), steep hillsides (brae), enclosed valleys (hope), passes (hass), ridges (rig), flowing streams (burn), dry river beds (syke), knolls (knowe), gullies (gill), and ravines (cleuch). Because the seasonal variation in temperatures is relatively small in the Scottish Borders region, variations in altitude have large effects on the capacities of the land for productive use, particularly the length of the growing season and the nutritional quality of the vegetation. As altitude increases, temperatures drop, wind exposure increases, and the amount and quality of vegetation decreases. High rainfall and poor drainage produces excessively boggy soil that inhibits the breakdown of organic matter into minerals. As a result, outbye ground lacks important nutrients for plant growth and nourishment. These features are perceived by farmers and agricultural science to limit production on Border hills to extensive livestock farming characterized by a low carrying capacity of approximately one hectare of outbye land per breeding ewe.

Inbye land or "park" are areas of gently sloping or level terrain below an altitude of 300 meters where weather conditions are milder with a landscape of more fertile and nutritious pasturage than outbye. Its affordances are not those for hefting hill sheep. Instead, inbye land is usually fenced to form distinct and often named fields. Its altitude and slope topography 
afford improvements in the quality and capacity of the soil by farmers so that it can be planted for the arable cultivation of feed and/or for more intensive grazing of less hardy but more prolific sheep than hill sheep hefting the outbye.

\section{Hefting on: Becoming with the Landscape}

The affordances of outbye landscape not only limit its agriculturally productive use to sheep rearing but also to particular breeds of sheep whose capacities for reproduction and survival are genetically realized as an inherent part of living and becoming with the harsh conditions of outbye landscape. In Teviotdale, two breeds of sheep predominantly graze hill land: Blackface and South Country Cheviot. ${ }^{10}$ They are bred to maintain and enhance what farmers and shepherds identify as the two capacities that make them particularly suited to rearing lambs in relation to features of the outbye hill pastures.

The most important capacity of Blackface and South Country Cheviot breeds is hefting on to the outbye landscape. These two breeds are territorial grazers with an attributed instinct to actively establish and remain on a home range. Teviotdale hill sheep farmers described how hill sheep tend to move from the lower to the higher ground during the late afternoon and throughout the evening, spending the night at or near the tops of hills; and they tend to move from the higher ground to the lower ground in the early morning and throughout the day. As they range over the land during this diurnal grazing pattern, hill sheep "do the landscape" [to use Olwig's formulation] by learning about those topographical and pasturage areas of adaptive significance for eating, mating, lambing, and sheltering. These grazing domains organize the outbye landscape into hefts or cuts. They are unfenced areas of outbye that include a variety of topographical features-hilltops, small valleys, and areas of low-lying protected ground-where ewes find grass for grazing and shelter for lambing. As such, they consist of the known and remembered places where the ewes return to fulfill their survival needs, and in doing so they create and bond to the region in which they remain throughout their lives. One shepherd described the effects of this attachment as an "invisible fence." Both the area of the farm's hill land and the group of sheep that form an attachment to it are called a heft. In referring to both a group of sheep and a territorial division of hill land, a heft materializes the relationality of sheep and the place created by the way they move about and use the landscape in carrying out their lives. It is the mutually constitutive and consubstantial relation between a specific group of sheep and the distinct area of the hill landscape to which they bond so that they become refractions of each other.

The breeding program of hill sheep farms is organized by hefts. Each year tups (rams) are restricted to mating with the ewes of only one heft, and ewes remain in the same heft over their breeding lives of five to six years. Every year, the oldest cohort, known as draft ewes, is replaced by a cohort of ewe lambs selected from those born of the ewes within the heft. ${ }^{11}$ Thus, a heft consists of four to five generations of breeding ewes bonded to a particular territory. One farmer described a heft as a "family line" consisting of "daughters of daughters." Further, because ewes stay on the same heft throughout their lives, they are understood to adapt to the characteristics of the land where they live and breed. Farmers and shepherds continually told me how their sheep had over generations become genetically adapted to the grasses and resistant to the parasites of their specific hefts. Other characteristics of a heft were also understood to be genetically embodied and transmitted: one shepherd commented that one heft of ewes had more twins than others; and another shepherd bragged that ewes of one of his hefts were particularly good mothers. The general understanding of hill sheep people was that 
each heft has distinctive characteristics that are "bred into them" and thus are passed down the generations through the selective breeding program. ${ }^{12}$ Hefting, then, is a process of the breeding and becoming of hill sheep in their dwelling with the landscape; through their moving and bonding with the heft (landscape), the behavior adaptations of sheep are transformed by the intentional breeding practices of hill sheep farmers into genetic capacities of the heft (group of sheep). In other words, sheep are their relation to the landscape.

The capacities that hill sheep become are correlates of the outbye landscape with which they heft. Hill sheep breeds are known for their "hardiness." By this farmers mean that the Blackface and South Country Cheviot sheep can survive on the open hill throughout the winter months without large inputs of supplementary feed. Other breeds of lowland or inbye sheep would perish. Because hill pastures in winter do not afford enough nutrition to maintain both mother and the gestating lamb, ewes lose body weight over the breeding cycle making them less productive..$^{13}$ Outbye sheep in comparison with lowland breeds have a genetic capacity to convert reserves of body fat and protein more quickly into energy and nourishment for the fetus (Hill Farm Research Organisation 1979, p. 55). ${ }^{14}$ Contributing to this hardiness is the wool or "skin" of hill sheep. While their fleece is coarse, rough and not suited to high quality wool products, it has high insulating properties that provide protection against heat loss during the wet and windy winters on exposed hill terrain. They are able to withstand under-nourishment in winter because their wool reduces the level of metabolism needed to maintain body heat. This in turn reduces the amount of supplementary feeding that farmers need to provide to pregnant ewes to minimize weight loss on the hill during winter. As a result, Blackface and Cheviot ewes can remain on outbye pasture throughout the year supported by the smaller amounts of supplementary feed that can be delivered to the largely vehicle-inaccessible hill pastures; they do not need to be brought into the lower altitude inbye pastures to gestate and feed their lambs.

I reiterate here for future reference that in describing to me the nature of a heft and the bonding of sheep and territory that the concept expresses, hill farming people employed a genetic discourse: in hefting on and living with the same heft over generations, a line of sheep comes to literally embody the outbye landscape in their genetic constitution. In this process there is a permeability between the landscape and sheep as well as between acquired behavioral adaptation and genetic transmission. What in the early generations of ewes was a specific behavioral adaptive relation to the landscape became, through the selection of replacement stock, a part of the genetic make-up of the ewes of succeeding generations. This is perhaps a more profound sense of the term heft and how it constitutes and unifies the seemingly separate phenomena of a particular group of sheep and the landscape with which they heft. Or to say this in a more heuristic way, a "heft" is both the process of creating and the resultant attachment between a group of beings linked by descent and a landscape imbued with a sense of emplacement.

\section{Becoming with Sheep: Herding, Movement and Emplacement}

Borders hill sheep farms use a distinctive method of shepherding that appropriates the affordance relation between the outbye landscape and the hefting capacity of the sheep that bond to it with the intentional practices of humans toward both the landscape and sheep. Spatially contiguous hefts [both areas of land and the ewes that territorially bond to it] are combined in the organization of a farm's flock to form a "hirsel," a term that refers simultaneously to the sheep for which one shepherd is responsible and the area of the hill where they graze. Like the concept of heft, a hirsel is a relation that unifies beings and place but this time including three 
elements: shepherd, sheep, and outbye landscape. The difference between hirsel and heft is that a heft relates and unifies sheep and the place created by the ways ewes move over, use, and become attached to the land; a hirsel relates and unifies sheep and the place created by the way shepherding is organized and by the movement of herds - by foot or by bikeintertwining with the movement of sheep.

This double sense of the concept of hirsel-referring simultaneously to a group of sheep and the area of land with which they heft-also entails a nested doubleness in the relationship between shepherd and hirsel resulting from the particular way shepherding involves an intertwining of movements of herd ${ }^{15}$ and sheep. Shepherding is an intimate relationship between a herd and the hirsel of sheep who have themselves created their places through hefting onto contiguous areas of hill land. At the same time and internally, shepherding is also a relationship between a herd and the hirsel of land; this relationship and the sense of place it creates for the herd are mediated by the hefting of the constituent cuts of sheep onto the hirsel of land and the herd's movement over that area of land.

\section{Becoming with Sheep: Shepherd's Sense of Self}

Shepherding a hirsel entails a lone herd traversing the outbye landscape on treks that cover 10 to 12 miles. The overall brief is to maintain sheep in their hefts and to watch over and care for sheep through the breeding cycle. ${ }^{16}$ Because of the poor quality of outbye land and harsh weather conditions, hill sheep farming is relatively small in scale, with flocks ranging from 400 to 2,000 breeding ewes. This magnifies the significance of each ewe for the financial success of the farm and increases the intensity of labor expended upon them. A hill hirsel consists of between 800 and 1,000 ewes, ${ }^{17}$ and herds are expected to walk or bike around the hills relatively frequently - two to three times a day during lambing, twice a day from lambing until clipping in June when ewes are likely to "cowp,"18 again twice a day in tup time (November) to ensure the tups are working, and once each day during other periods.

Such relatively intense shepherding brings herds in close contact with their sheep. Such closeness, however, does not just have a physical dimension but is measured in terms of the quality and intimacy of knowledge that results from moving and working with them. When going around the hill, shepherds draw near enough to each ewe so that it is literally seen at least once on every trek. Often shepherds will stop for several minutes - at a distance that does not scatter the sheep-just looking over a group of sheep as they graze. If there is a problem, it will be dealt with quickly and the results of the treatment closely monitored. Such frequent seeing and handling results in shepherds knowing some individual characteristic of many ewes in the hirsel: the shape of the nose, the way one carried her ears, a ewe off a prize tup, one that likes to rest in a special place in the morning after grazing, the one that was "yeild"19 last year. In almost every discussion of shepherding I engaged in, herds and farmers emphasized that one of the characteristics of a good shepherd is the ability to "ken the sheep" or be a good "kenner." By this they meant the ability to visually recognize individual sheep and their unique physical attributes as well as to remember their history, bloodline, and distinctive behavioral habits, such as where they like to lamb. ${ }^{20}$ One shepherd described a good kenner [knower] as follows:

It's only when you're with sheep all the time that you develop your ability as a kenner ... you can learn about the ability of people as kenners by watching them at Shows ... if you have 150 sheep in a pen and a ewe from another pen jumps in among the 150 sheep, that's when you know who is a kenner, the one who can pick out the ewe that jumped into the pen. 
One of the outcomes of this intensive shepherding is that a herd's personhood-his stockmanship, herding skills, and knowledge of sheep-are judged by the quality of the ewes and lambs in his hirsel. It is recognized that over time under the care of a shepherd, a hirsel of sheep comes to embody his personhood. This understanding - that the physical attributes of a hirsel of sheep objectifies the shepherd who cared for them-parallels the way hill sheep people, as I described earlier, use a genetic discourse to explain the characteristics of a heft of sheep and its embodiment of the landscape to which it is bonded. Thus, through hill herding - a practice in which the movement and lives of herds and sheep intertwine-outbye sheep come to embody and mediate the relation between a farm's outbye landscape and the humans living with it, both co-mingling in the sheep's genetic constitution which is the product of the hefting.

\section{Becoming with Sheep: Shepherd's Sense of Place}

Shepherding is also emplacing - of relating person to place. In walking or biking over the hill terrain, herds create an attachment or bond between themselves and their hirsels that is analogous to, and at the same time mediated by, the hefting of sheep. This sense of place happens in the sensuous act of walking and biking over the landscape in much the same way as the urban pedestrians described by de Certeau (1984). Descending from the 110th floor of New York's World Trade Centre into the streets, he follows the wandering footsteps of the people who use the city. "Neither author nor spectator" (de Certeau 1984, p. 93), pedestrians appropriate it kinaesthetically through practices that resist the normative meanings of the anonymous subjects presumed by cartographers and city planners. "Space is practiced place"21 (de Certeau 1984, p. 117) where historically and culturally situated people create a locality of familiar heres and theres in the same way as speakers act out the language system in the creation of vernacular meanings. It is de Certeau's image of this constitutive walking in the city which suggests a way of understanding hill sheep herding as a process of emplacement. Ingold invests walking with a similar experiential and meaning-producing significance. For him, walking is an instance of Sheets-Johnstone's concept of "thinking in movement" (Ingold and Vergunst 2008, p. 2), an almost primordial, "tactile, feet-first engagement with the world" (Ingold and Vergunst 2008, p. 3). ${ }^{22}$

In their movement through their hirsels, shepherds follow established paths and they identify two principles for constructing them. The first is to adapt the direction of their movement around the hirsel so that they intertwine with grazing habits of the hefting sheep. As described earlier, sheep tend to move up the hills during the late afternoon and throughout the evening, spending the night at or near the tops of hills, and down the hills in the early morning and throughout the day. Based upon their detailed knowledge of how the hefts of sheep on their hirsels used the topographical features of the land, shepherds constructed their paths in order to come up behind but be moving in the same direction as the sheep so that they pushed them in the direction they were naturally going. Because sheep move in different directions in the morning and evening, there were different paths for going around the hill depending upon the time of day. The stated pattern was for the path to "go around the tops [of the hills]" in the morning in order to drive the sheep down and "to go around the bottoms [of the hills]" in the evening in order to drive the sheep up. This practice, known as "maintaining the hefts," consisted of a shepherd keeping a hirsel of sheep in their proper place by gathering them together as groups in their hefts every morning and evening. If a shepherd walked "against" the natural movement of sheep, he would scatter them. ${ }^{23}$ 
The particular order in which a shepherd goes from heft to heft was adapted to the topography of the land and the grazing habits of the sheep such that he always came in behind their movement through the landscape. Shepherds recognized two topographically different types of hirsels that affected the morning and evening circuits. One type is a "rig hirsel" whose prominent topographical feature is a single ridge top with the hefts of sheep that form the hirsel spreading down the slopes on both sides. On this type of hirsel, the morning route "around the tops" generally follows the ridge, and the evening route along the bottom of the slopes makes a long circuit around the ridge. The other type is a "hope hirsel" formed by horseshoe-shaped hills forming its outside limits with hefts of sheep spreading inwards toward the central valley enclosed by the hills. The morning path is around the tops while the evening is a circuit into the valley.

The second principle of constructing a path around a hill hirsel is that it should be adapted to the terrain in order to allow a shepherd to see all the ground of the hirsel so that if a sheep is in trouble anywhere on the hill, he would be able to observe it during his round and take remedial steps so that he would not end up with a dead sheep. Because the topography of the land is complex with intersecting hills, ridges, ravines, knowles, streams, tall grasses, bracken, moss, and heather, shepherds become familiar with all the areas where a sheep would be difficult to see. The paths they established meander and double back over landscape to ensure that they could see every part of the hirsel during their rounds. During my many walks around the hills with shepherds, each pointed out to me locations that were "not very sighty ground." These were places that were difficult to see from their paths-in dips and sykes, behind knowles, in bracken. They remembered them as places where sheep had died because they could not be seen from the paths; and they described how they had modified the path so that these places could be seen. In these practices, seeing was a form of shepherds doing the landscape by creating meaningful places with respect to events in the lives of sheep and their memories of them. Paths were created in order to see these places; and seeing these places as part of following a path was a gathering of them into a hirsel. Spatially then, a hirsel was a set of places that interweave the activities of sheep carrying out their lives on the hill and the activities of humans in going around the hill. ${ }^{24}$

\section{Genetic Logic and Sense of Place}

In ending this paper, I return to the genetic logic of hefting and the embodiment of a herd's stockmanship in his hirsel of sheep and show how it is extended by farmers in experiencing their attachment to farms. It is a deeply and sensuously felt sense of place that makes their farms "family farms" that they hope to pass on to the next generation.

The process of succession of the farm to the next generation begins with the birth of a child and ends with the death of the parents. The goal of the transmission strategies adopted by farming families is to ensure there is a financially viable farm that can be legally passed on to the next generation of the family. Yet what makes a "family farm business" - to use Gasson and Errington's (1993, p. 12) term - a family farm to people in Teviotdale is a consubstantial rather than a legal relation between family and farm, so that these strategies by themselves are not sufficient to reproduce that relation over time. Herein lies the significance of the genetic logic that is used to describe the embodiment of place produced in hefting with the land. It is used in Teviotdale to explain how people acquired a range of attributes including their individual personality, the behavior patterns and attitudes characteristic of a social class and/or region, and the skills, aptitude, and temperament for farming. These attributes were said to be "bred into" 
a person, that is, acquired and transmitted through genetic processes such that they inhered in the person's body. Here farmers' knowledge of the genetic mechanism of sheep breeding gained in their everyday farming activities is used to conceive of the process through which people acquire and transmit attributes. One farmer explicitly recognized the metaphorical character of using breeding in this way: "People around here have been breeding sheep for a long time and they get ideas from this ... so they explain the likeness in family members from watching bloody sheep!" It was evident to this farmer that the metaphor builds upon how consubstantiality was produced and reproduced in sheep through hefting, shepherding, and breeding practices. As we have seen above, hill sheep farmers "know" that sheep acquire, embody, become, and transmit genetically a range of attributes: physiological attributes of body conformation, meat-to-fat ratio, ability to produce milk for lambs, and quality of wool; behavioral attributes of temperament and adaptations to the particular vegetation, pests, and soils of the outbye landscape where they graze and to which they bond through hefting; and the social/relational attributes of the skills of the shepherd who herds them and the farmer who selects the tups for breeding. It was this practical knowledge of sheep breeding that "gives them ideas" for explaining the attributes of people.

When used in relation to farming, the metaphorical extension of this practical knowledge was epitomized by two phrases that Teviotdale farmers used often in talking about each other: "farming is bred into you" and "good farmers come from farming families." In these phrases they were propounding a theory of a genetic mechanism for the becoming and intergenerational transfer of those attributes that were necessary to be a farming person. In such a theory, the aptitude for farming was corporeal so that personhood and farming co-mingled in a common substance that appeared to be transmitted genetically in the same way that sheep embody the landscape and farming people. One farmer described hill sheep farmers in the Borders as follows: "They are a special kind of farmer in Britain. They will put up with bad times and stick with their farms until good times come again. Such stick-to-it-ness is bred in them." The metaphor was also behind the way farmers talked about themselves. Almost the first thing farmers told me about themselves or about other people was to place themselves or others in a genealogy of farming families. The implication was that people acquired and inherited their farming prowess from their families. The following are two examples of this:

James is a good farmer. His family has been on the farm for over 100 years. In the 1870s, James' great grandfather came into the farm from a farm in Ettrick. At the time, his grandfather was twelve years old. His mother's father was a shepherd at Falnash Farm for twenty-nine years, and then he became the shepherd working for James' father. Before his work at Falnash, James' mother's father was a shepherd at Craik. James' wife's family are farmers at Bonchester; his wife's sister is still in farming. She and her husband own a farm in South Eden.

I'm from a farming family who have [been in] Catslackburn Farm in Yarrow for generations. My two brothers are still on that farm.

This genetic logic was also applied to the relation between particular families and particular farms through the mediation of hefting sheep. As I described earlier, the farm's land and the family inhered in the flock's genetic constitution through breeding practices and these same practices transmitted the adaptations and the consubstantiality of sheep, farm land, and farm family to succeeding generations of sheep to form a genealogical line that was characteristic 
of the farm as a whole. As a result, sheep were both the embodiment and the icon of the consubstantiality that was a family farm. Further, farmers' knowledge of these processes provided a practical understanding of the nature of consubstantiality that intertwines the lives of animals, humans and place; it is a corporeal configuration of a descent-based group with a specific territory over generations. Through both the genealogical bias in tenancy laws and the strategies adopted by family farmers to ensure the legal and financial transfer of a farm to their children, family farms come to resemble their flocks' hefting relation to the hills where they graze: both are descent groups associated with a particular territory over several generations. But sheep literally and figuratively transpose the legal and financial mechanisms of transfer into genetic mechanisms so that it is also farm-family consubstantiality that is passed on to the son and his family. It explains why I never heard of any son buying in a new flock when he took over a farm from his father, no matter how strained the family relations.

Hefting as emplacement and the genetic logic it entails is the basis of the conflation of farm and family in everyday talk - a dialogic conflation that manifests the fundamental relationality of a family becoming with the farm through hefting. Perhaps the most striking example that I came across happened at an annual meeting of the Upper Teviotdale Agricultural Show Committee. In the discussion of who would take over the Presidency of the Committee, the Secretary suggested Robert, the son of the current President, Willie Scott. In trying to avoid the suggestion, Robert responded: "Aren't there any other families in the Valley? Braeside is always doing the kirk, the Show and the School." Here The Scott Family and Braeside Farm, which they had occupied for three generations, were used interchangeably. Like a heft and hirsel, family and farm (being and place) were two ways of referring to the same thing.

\section{Notes}

1. Understanding, rather than representing, animals as subjects and agents, however, does not necessitate either "egomorphising" (Milton 2005, p. 255) by projecting human qualities into them or speculating anything about the nature of animal intentionality, cognitive abilities, or affective capacities.

2. Ingold (2011, p. 70) is also concerned with problems with relational perspective in networks.

3. Hislop and Falnash were combined into one farm in the mid-1980s.

4. Most farms also raise suckler cows but this accounts for less than $20 \%$ of the total grazing livestock (Anderson 1986, p. 14).

5. I am using a simplified definition of family farm: members of a family are the owners, tenants, or partners of the farm, own the sheep, and provide most of the labor. There has been a long debate on the definition of family farms (see Gasson and Errington 1993; Hill 1993; Djurfeldt 1996; Gray 1998).

6. Three farms are owner occupied. Six are under traditional tenancy with the farmer paying an annual rent to a landlord -in most cases the Buccleuch Estate - in return for the right to live on the farm and use the land for agricultural production. Five are partnerships with the Estate that owns the farm. A partnership is a form of tenure introduced in the 1980s under which the farmer and the Estate form a legal partnership. Both parties contribute equal amounts of capital to the farm business; the farmer partner agrees to ensure a return on investment to the Estate, provides the livestock, and pays an annual rent to the Estate. One is run by a salaried live-in manager hired by the owing estate. Hill sheep farmers, whether owner occupiers, tenants, or partners, own the sheep which have a capital value of between $\$ 30,000$ on the smaller farms and $\$ 125,000$ on the largest farms.

7. Ingold (2011, p. 78) makes a similar critique of Gibson.

8. What I have termed the outbye "landscape" is a complex object that contains a variety of elements, some of them inanimate (soil) and some of them animate (flora and fauna). Gibson treats plants as inanimate but as Reed points out: "plant action is far more limited than animal, but plants do move and react ... Plants have a rudimentary awareness of their surroundings, especially their chemical and meteorological aspects. Perhaps animate versus inanimate is a dimension, with plants in the middle or perhaps plants form a separate category altogether" (Reed 1988, p. 112). 
9. For hill sheep farmers, their current perception of differential affordances of inbye and outbye land for agricultural use are based upon the practices of hill sheep farming in the border hills since the seventeenth century (see Robson 1977, 158ff) supplemented by information from Government Departments and the science of agricultural research organization. The most important of these for hill sheep farming are the Hill Farming Research Organisations, The Macaulay Land Use Research Institute with which it merged in 1987 which in turn joined with the Scottish Crop Research Institute to form the James Hutton Institute in 2011.

10. After the Foot and Mouth Disease outbreak in 2001, some of the farms whose flocks had to be culled have restocked with a type of North Country Cheviot suited to upland and hill pastures, locally called "Hill Northies."

11. Draft ewes are usually sold at auctions either for their carcass or for cross-breeding with park rams on lowland farms for another year or two of fat lamb production.

12. This "breeding in" of the adaptive relation between a heft of sheep and a grazing place was the reason why, when a farmer "comes into" a farm, either by purchase, tenancy, or partnership, s/he buys the hill ewes already on the farm rather than bringing ewes from the previous farm.

13. Compared with inbye sheep, hill ewes have fewer multiple births making them less productive, an effect largely due to the poor quality of the hill pastures that results in a lower ovulation rate. In addition, hill lambs are usually too small to meet the EU criteria of fat lambs leaving farmers with two options. One was to sell hill lambs on the store market to lowland farmers in Scotland and England who fattened them in their fields and then sold them several months later on the fat market. The other now more prevalent option is to bring the lambs off the hill and fatten them on the farm's inbye land for several months when they can be sold on the fat market.

14. The Hill Farm Research Organisation suggests that one of the major impediments to hill sheep productivity is "the 'hungry gap' period from January to April, when hill pastures provide only a minimum growth and when the majority of hill ewes, though pregnant, live on a sub-maintenance diet and decline in weight" (1979, p. 42).

15. Sheep farming people in the Scottish Borders use the term "herd" as it is used in the Scot language: "a person who tends or watches over sheep ... esp. in order to confine them to a particular pasture in unfenced areas [i.e. hefts]" (Robinson 1985, p. 282, brackets added).

16. There are several tasks - dipping, weaning, castrating, selecting lambs for sale or replacement stock - that are done with other farm personnel, but these represent only a small proportion of a shepherd's yearly routine.

17. On other types of sheep farms located on more productive land, shepherds may be responsible for 2,000 sheep. One shepherd, who had been a shepherd in New Zealand, said that he had been responsible for over 5,000 sheep and hardly had any contact with them except occasionally from the cab of a jeep.

18. "Cowping" refers to the tendency of ewes in late spring, when they are heavy with wool and weak from lambing, to fall over on their backs. If they do not right themselves, gas builds up in their stomachs leaving too little space for their lungs to expand so that they eventually suffocate.

19. A yeild ewe is one that did not become pregnant.

20. Such knowledge of individual sheep is recognized by Knight as a form of personhood for animals (2005, pp. 2-3).

21. The terminology used by de Certeau to distinguish between "place," that is, localities as positions on maps and plans and "space," that is, meaningful localities constituted through practice is the reverse of the terminology used by many phenomenological geographers (see, e.g., Pickles 1985; Relph 1985). I use de Certeau's terminology here because I am drawing upon his ideas in framing the analysis.

22. Shepherds' use of a quad-bike instead of walking to go around their hirsels remains a fundamentally tactile practice, an instance of de Certeau's constitutive movement and Sheets-Jonstone's thinking/significance-creating in movement. Shepherds told me that riding quad-bikes over the terrain is as sensuous as walking, if not more so. The movements of the bike as its tires react to the slopes, sykes, boggy soil, streams, and bumpy ground, as well as the increased experience on the skin of any cold, wind, and rain that the speed of the bike produces, are all felt through the bike by the rider with his body just as a walking herd feels them through his body. Some herds said that riding a bike over the terrain exaggerates the tactile experience of the characteristics of the landscape, making them more noticeable. This is because they have to pay close attention to the terrain over which they are travelling, now at greater speed and danger than walking, to ensure their safety; and they still have to look at the sheep as closely, often stopping the bike at various points to visually examine the sheep to see if there are any problems that need their attention. 
23. This practice also maintains the hefts in land management sense, since the movement of sheep over the land ensures even grazing and "clean ground" where there is not an excessive build up of dung where fluke can become a problem.

24. Seeing - and gathering - everything, however, did not mean that paths had to go everywhere in the hirsel. The hilly terrain allowed shepherds to clearly see some parts of the hirsel from strategically located vantage points. As I walked around the hill with another shepherd, he explicitly stopped at various points on the path to show me the places he had created where, he said, "it is good to have binoculars because I can see parts of my hirsel from a long distance away and I don't have to walk there if there's nothing wrong [with the sheep] ... if something is wrong, I can go there and sort out the problem." As another shepherd put it: "My two most important pieces of equipment are the bike and the binoculars ... I have found places on the farm that are good vantage points so that I don't have to ride the bike over every inch of land."

\section{References}

ADAS, UK. Ltd. 2008. Literature review on the practice of hefting. In Assessment of the Impact of Hefting (Heafing or Learing). DEFRA: Research Project Final Report (Reference BD1242).

Anderson, J. L. 1986. Profitability of Farming in South East Scotland 1984/85. Edinburgh: The East of Scotland College of Agriculture, Agricultural Resource Management Department.

Basso, K. H. 1996. Wisdom Sits in Places: Landscape and Language among the Western Apache. Albuquerque, NM: University of New Mexico Press.

Casey, E. 1993. Getting Back into Place: Toward a Renewed Understanding of the Place-World. Bloomington, IN: Indiana University Press.

Casey, E. 1996. How to get from space to place in a fairly short stretch of time. In Senses of Place, 13-52, ed. S. Feld and K. Basso. Santa Fe, NM: School of American Research Press.

de Certeau, M. 1984. The Practice of Everyday Life. Berkeley, CA: University of California Press.

Chemero, A. 2003. An outline of a theory of affordances. Ecological Psychology 15(2): 181-195.

Djurfeldt, G. 1996. Defining and operationalising family farm from a sociological perspective. Rural Sociology 36(3): 340-351.

Gasson, R. and Errington, A. 1993. The Farm Family Business. Wallingford, UK: CAB International.

Gibson, J. J. 1979. The Ecological Approach to Visual Perception. Boston: Moughton Mifflin.

Goddard, A. n.d. Hefted sheep-a phenomenon cast aside? www.sovereignty.org.uk/features/footnmouth /hefted1.html. Accessed on June 20, 2011.

Gray, J. 1998. Family farms in the Scottish borders: A practical definition by practical farmers. Journal of Rural Studies 14(3): 341-356.

Haraway, D. 2008. When Species Meet. Minneapolis: University of Minnesota Press.

Hart, E. 2004. Hefting in Practice: The Ancient Craft of Grazing on the Open Hills. Private printing.

Heidegger, M. 1962. Being and Time. New York: Harper and Row.

Heidegger, M. 1975. Building, dwelling, thinking. In Poetry, Language, Thought. New York: Harper and Row.

Hill, B. 1993. The "myth" of the family farm: Defining the family farm and assessing its importance in the European Community. Journal of Rural Studies 9(4): 359-370.

Hill Farming Research Organisation. 1979. Science and Hill Farming: Twenty-Five Years of Work At the Hill Farming Research Organisation, 1954-1979. House o' Muir, Scotland: Hill Farming Research Organisation. Ingold, T. 2011. Being Alive: Essays on Movement, Knowledge and Description. London: Routledge.

Ingold, T. and Vergunst, J. L. 2008. Introduction. In Ways of Walking: Ethnography and Practice on Foot, 1-20, ed. T. Ingold and J. L. Vergunst. Aldershot, UK: Ashgate.

Knappett, C. 2004. The affordances of things: A post-Gibsonian perspective on the relationality of mind and matter. In Rethinking Materiality: The Engagement of Mind with the Material World, 43-51, ed. E. DeMarrais, C. Gosden and C. Renfrew. Cambridge: McDonald Institute Monographs.

Knight, J. 2005. Introduction. In Animals in Person: Cultural Perspectives on Human-Animal Intimacies, 1-14, ed. J. Knight. Oxford: Berg Publishers.

Latour, B. 2005. Reassembling the Social: An Introduction to Actor-Network-Theory. Oxford: Oxford University Press.

Levi-Strauss, C. 1963. Totemism. Boston: Beacon Press. 
McGrenere, J. and Ho, W. 2000. Affordances: Clarifying and evolving a concept. In Proceedings of Graphics Interface 2000. http://www.graphicsinterface.org/proceedings/2000/177/PDFpaper177. pdf. Accessed on December 7, 2011.

Milton, K. 2005. Anthropomorphism or egomorphism? The perception of non-human persons by human ones. In Animals in Person: Cultural Perspectives on Human-Animal Intimacies, 255-271, ed. J. Knight. Oxford: Berg Publishers.

Mullin, M. H. 1999. Mirrors and windows: Sociocultural studies of human-animal relationships. Annual Review of Anthropology 28: 201-224.

Norman, D. A. 1998. The Design of Everyday Things. London: MIT Press.

Olwig, K. R. 2008. Performing on the landscape versus doing landscape: Perambulatory practice, sight and the sense of belonging. In Ways of Walking: Ethnography and Practice on Foot, 81-92, ed. T. Ingold and J. L. Vergunst. Aldershot, UK: Ashgate.

Pickles, J. 1985. Phenomenology, Science, and Geography: Spatiality and the Human Sciences. Cambridge: Cambridge University Press.

Reed, E. S. 1998. The affordances of the animate environment: Social science from the ecological point of view. In What Is an Animal, 110-126, ed. T. Ingold. London: Routledge.

Relph, E. C. 1985. Geographical experiences and being-in-the-world: The phenomenological origins of geography. In Dwelling, Place and Environment: Towards A Phenomenology of Person and World, 15-31, ed. D. Seamon and R. Mugerauer. Dordrecht, The Netherlands: Marinus Nijhoff Publishers.

Robinson, M. 1985. The Concise Scots Dictionary. Aberdeen: Aberdeen University Press.

Robson, M. J. H. 1977. History and traditions of sheep-farming in the Scottish Border hills: A study of customary life and practices among the sheepfarming community of the Central Hill area before 1900. PhD thesis, University of Edinburgh, UK.

Thomas, J. 1993. The politics of vision and the archaeologies of landscape. In Landscape: Politics and Perspectives, 19-48, ed. B. Bender. Oxford: Berg Publishers. 